\title{
Gambaran Kecemasan Anak Usia 6-12 Tahun terhadap Perawatan Gigi di SD Kristen Eben Haezar 2 Manado
}

\author{
${ }^{1}$ Seily E. Sanger \\ ${ }^{2}$ Damajanty H. C. Pangemanan \\ ${ }^{1}$ Michael A. Leman \\ ${ }^{1}$ Program Studi Pendidikan Dokter Gigi Fakultas Kedokteran \\ ${ }^{2}$ Bagian Fisiologi Fakultas Kedokteran \\ Universitas Sam Ratulangi Manado \\ Email: sanger.seily@gmail.com
}

\begin{abstract}
Dental anxiety is a condition of fear to visit a dentist even for preventive care or therapy and uncertainity anxiety to dental care. This study was aimed to describe the anxiety of children 6-12 years old for the dental care at SD Kristen Eben Haezar 2 Manado. This was a descriptive study with a cross-sectional design. Samples were 44 students of 6-12 years old at SD Eben Haezar 2 Manado who had dental care experience, obtained by using total sampling. Data were obtained by filling the questionnaire of Children Dental Fear Survey Schedulesubscale (CFSS-DS). The results showed that most students with high levels of anxiety were at the age of 6-8 years $(20.48 \%)$, while most students with low level of anxiety were at the age of 9-12 years old $(47.74 \%)$. Of the 44 students, 27 students $(61.36 \%)$ had low level of anxiety whereas 17 students (38.64\%) had high level of anxiety. Based on gender, the percentages of students with high level and low level of anxiety were higher in females than in males. Conclusion: In general, students with low level of anxiety were at the age of 9-12 years old meanwhile students with high level of anxiety were at the age of 6-8 years. Either high or low level of anxiety was most found in females.
\end{abstract}

Keywords: anxiety, children, dental care

\begin{abstract}
Abstrak: Kecemasan dental merupakan suatu ketakutan terhadap kunjungan ke dokter gigi untuk perawatan pencegahan ataupun terapi dan rasa cemas tidak beralasan terhadap perawatan gigi. Penelitian ini bertujuan untuk mendapatkan gambaran kecemasan anak usia 612 tahun terhadap perawatan gigi di SD Kristen Eben Haezar 2 Manado. Jenis penelitian deskriptif dengan desain potong lintang, mengunakan metode pengambilan sampel total. Terdapat 44 siswa aktif SD Kristen Eben Heazer 2 Manado berusia 6-12 tahun dan pernah mendapatkan perawatan gigi. Data diambil berdasarkan pengisian kuesioner Children Fear Survey Schedule-Dental Subscale (CFSS-DS). Hasil penelitian menunjukkan responden dengan tingkat kecemasan tinggi ditemukan paling banyak pada usia 6-8 tahun (20,48\%), sedangkan yang dengan tingkat kecemasan rendah ditemukan pada usia 9-12 tahun (47,74\%). Tingkat kecemasan rendah ditemukan pada 27 responden $(61,36 \%)$ dan tingkat kecemasan tinggi ditemukan pada 17 reponden $(38,64 \%)$. Berdasarkan jenis kelamin, responden dengan tingkat kecemasan tinggi maupun rendah lebih banyak ditemukan pada responden perempuan. Simpulan: Responden dengan tingkat kecemasan rendah lebih banyak didapatkan pada rentang usia 9-12 tahun sedangkan responden dengan tingkat kecemasan tinggi lebih banyak didapatkan pada rentang usia 6-8 tahun. Baik tingkat kecemasan tinggi maupun rendah lebih banyak ditemukan pada responden perempuan.
\end{abstract}

Kata kunci: kecemasan, anak, perawatan gigi 
Data dari Riset Kesehatan Dasar (Riskesdas) tahun 2013 tentang persentase penduduk Indonesia yang mempunyai masalah gigi dan mulut sebesar $25,9 \%$ dan $31,1 \%$ yang menerima perawatan dan pengobatan dari tenaga medis gigi (perawat gigi, dokter gigi, atau dokter gigi spesialis). Persentase menurut kelompok usia 5-9 tahun yang bermasalah dengan gigi dan mulut sebesar $28,9 \%$ dan yang menerima perawatan tenaga medis gigi sebesar $35,1 \%$. Kelompok usia 10-12 tahun yang bermasalah dengan gigi dan mulut sebesar $25,2 \%$ dan yang menerima perawatan dari tenaga medis gigi $28,3 \%{ }^{1}$

Anak usia 6-12 tahun merupakan anak usia sekolah, dan usia ini merupakan masa laten. Selama masa ini, anak mengembangkan kemampuannya bersublimasi, dan apa yang telah terjadi dan dipupuk pada masamasa sebelumnya akan berlangsung terus untuk masa-masa selanjutnya dan sebagai masa perluasan kontak sosial dengan orang-orang di luar keluarganya. ${ }^{2}$ Meningkatnya rasa tanggung jawab terhadap tugas sekolah dan tugas di rumah akan lebih terlihat pada anak usia ini. ${ }^{3}$

Kecemasan perawatan gigi berawal dari masa anak-anak (51\%) dan remaja (22\%). Salah satu aspek terpenting dalam perawatan gigi ialah mengontrol rasa cemas anak. Kesehatan gigi dan mulut anak merupakan hal yang sangat penting dalam masa pertumbuhan anak. Kebutuhan perawatan gigi anak seperti tindakan preventif, aplikasi fluor, pit dan fissure sealant perlu diperkenalkan dan dilakukan pada pasien anak sebelum gigi mengalami kerusakan. ${ }^{4}$

Kunjungan ke dokter gigi sering membuat anak merasa cemas. Kecemasan anak yang dihubungkan dengan perawatan gigi disebut dental anxiety. Kecemasan dental menurut Klingberg dan Broberg adalah suatu keadaan tentang keprihatinan bahwa sesuatu yang mengerikan akan terjadi sehubungan dengan perawatan gigi atau aspek tertentu dari perawatan gigi. ${ }^{5}$ Sebuah hasil penelitian menunjukkan bahwa jenis perawatan gigi yang paling menakutkan pada anak ialah penyuntikan, pencabutan, dan pengeboran. Penelitian yang dilakukan oleh Alaki et al. ${ }^{6}$ di India, terhadap 518 anak-anak yang diteliti tingkat kecemasannya terhadap pencabutan gigi mendapatkan sebesar $43,5 \%$ anak lakilaki dan $64,6 \%$ anak perempuan menyatakan kecemasan terhadap prosedur pencabutan gigi karena anak-anak merasa bahwa alat-alat kedokteran gigi yang berada di dalam tempat praktek sangat menakutkan dan mengakibatkan rasa nyeri.

Kecemasan yang timbul mulai dari masa anak-anak merupakan hambatan terbesar bagi dokter gigi dalam melakukan perawatan yang optimal. Prevalensi kecemasan dental di semua negara begitu tinggi mencapai 6-15\% dari seluruh populasi. $^{7}$ Kecemasan merupakan faktor psikologis afektif yang memengaruhi persepsi rasa nyeri. Kenyataannya, kecemasan mengakibatkan persepsi yang seharusnya tidak nyeri menjadi nyeri, bahkan pada kondisi yang berbeda seorang pasien dapat menunjukkan reaksi yang berbeda meskipun rangsangan sama. ${ }^{8}$

Kecemasan dental pada anak dipengaruhi oleh beberapa faktor di antaranya: faktor personal (usia, tempramen, dan jenis kelamin); faktor eksternal (parental anxiety, vicarious learning, dan situasi social); faktor dental (rasa sakit dan lingkungan dental. ${ }^{9}$ Hasil penelitian yang dilakukan oleh Rafdi ${ }^{10}$ tentang gambaran kecemasan anak usia 7-14 tahun terhadap perawatan gigi di SD Inpres Tamalanrea II Makassar mendapatkan frekuensi kecemasan tertinggi berdasarkan jenis kelamin pada responden perempuan sebesar 101 sampel $(51,3 \%)$, dan pada responden lakilaki sebesar 96 sampel (48,7\%).

Peran sekolah sangat diperlukan dalam upaya pemeliharaan kesehatan gigi dan mulut anak, karena faktor lingkungan salah satunya ialah sekolah yang memiliki kekuatan besar dalam menentukan perilaku. ${ }^{11}$ Hasil survei awal di SD Kristen Eben Haezar 2 Manado yang memiliki 487 siswa di tahun ajaran 2016, dengan latar belakang perekonomian menengah ke atas rata-rata, mendapatkan bahwa pada sekolah ini belum pernah dilakukan penelitian dan penyuluhan mengenai kebersihan gigi dan 
mulut serta perawatannya, dan tidak adanya program Usaha Kesehatan Gigi Sekolah (UKGS).

\section{METODE PENELITIAN}

Jenis penelitian yang digunakan dalam penelitian ini yaitu deskriptif dengan desain potong lintang. Penelitian ini dilaksanakan di SD Kristen Eben Haezar 2 Manado dengan populasi yaitu siswa SD Kristen Eben Haezar 2 Manado sebanyak 487 siswa. Kriteria inklusi terdiri dari anak usia 6-12 tahun, pernah mendapatkan perawatan gigi sebelumnya minimal $1 \mathrm{x}$ dalam jangka waktu 1 tahun terakhir, bersedia menjadi responden dengan mengisi lembar persetujuan penelitian (informed consent) yang disetujui oleh orang tua atau wali. Kriteria ekslusi yaitu anak yang tidak kooperatif saat menjalani prosedur penelitian. Teknik pengambilan sampel yang digunakan ialah total sampling.

Penelitian ini menggunakan kuesioner Children Fear Survey Schedule-Dental Subscale (CFSS-DS) yang telah diuji validitas dan reliabilitasnya dengan bantuan perhitungan SPSS. Berdasarkan hasil uji validitas kuesioner Children Fear Survey Schedule-Dental Subscale (CFSS-DS) untuk pengukuran gambaran kecemasan anak usia 6-12 tahun terhadap perawatan gigi di SD Eben Haezar 2 Manado, pada 30 sampel usia 6-12 tahun di tempat yang berbeda diperoleh hasil uji validitas dalam rentang 0,499-1,000. Hasil pengujian validitas kuesioner dikatakan valid jika nilai $r$ hitung untuk semua item pertanyaan lebih besar dari nilai $\mathrm{r}$ tabel (person product moment), dan nilai hasil pada uji validitas ini lebih besar daripada nilai ketetapan $\mathrm{r}$ tabel untuk 30 sampel yaitu 0,361, artinya kuesioner CFSS-DS ini valid. Berdasarkan uji reliabilitas yang menggunakan rumus koefisien reliabilitas Alpha Cronbach, dengan membandingkan nilai $r$ tabel dengan nilai alpha, dengan ketentuan bila $\mathrm{r}$ alpha $>0,60$ maka alat peneliti reliabel, dan pada uji reliabilitas kuesioner CFSS-DS ini diperoleh nilai $r$ alpha 0,924; semakin besar nilai $\mathrm{r}$ alpha yang diperoleh maka kuesioner Children
Fear Survey Schedule-Dental Subscale (CFSS-DS) semakin andal dan reliabel.

Penelitian ini diawali dengan mengajukan ijin melakukan penelitian ke SD Kristen Eben Haezar 2 Manado yang menjadi lokasi penelitian. Pengambilan data penelitian dilakukan berdasarkan tahapan: Anak yang menjadi responden diberikan lembar persetujuan penelitian (Informed Consent) dan kuesioner Children Fear Survey Schedule-Dental Subscale (CFSS-DS) sambil menjelaskan maksud dan tujuan penelitian. Anak yang setuju diminta menandatangani bagian tanda tangan dengan persetujuan orang tua/wali. Peneliti menjelaskan cara pengisian kuesioner CFSS-DS pada guru dan anak. Pada lembar kuesioner CFSS-DS pada bagian identitas hanya diberikan kode untuk menjaga kerahasiaan. Kerahasiaan informasi yang didapat oleh pasien dijamin oleh peneliti. Data hasil penelitian diolah berdasarkan distribusi frekuensi dan disajikan dalam bentuk tabel.

\section{HASIL PENELITIAN}

Responden yang diteliti pada penelitian ini ialah anak usia 6-12 tahun yang bersekolah di SD Eben Haezar 2 Manado dan pernah mendapatkan perawatan gigi. Jumlah responden saat penelitian yaitu 50 anak. Terdapat 44 anak yang masuk kriteria inklusi, dan 6 anak diesklusi karena tingkah laku anak yang tidak kooperatif selama penelitian berlangsung.

Responden dengan tingkat kecemasan rendah lebih banyak didapatkan pada rentang usia 9-12 tahun (47,74\%) sedangkan responden dengan tingkat kecemasan tinggi lebih banyak didapatkan pada rentang usia 6-8 tahun $(20,48 \%)$ (Tabel 1). Responden dengan tingkat kecemasan rendah dan tinggi lebih banyak didapatkan pada responden perempuan dibanding dengan responden laki-laki (Tabel 2). Terdapat lebih banyak responden yang memiliki tingkat kecemasan rendah daripada tingkat kecemasan tinggi pada penelitian ini (Tabel 3). Kecemasan terhadap perawatan dental lebih tinggi pada penyuntikan yaitu sebesar 9,08\% (Tabel 4). 
Tabel 1. Distribusi tingkat kecemasan berdasarkan usia

\begin{tabular}{ccccccc}
\hline Tingkat & \multicolumn{2}{c}{ Usia } & \multicolumn{2}{c}{ Usia } & \multicolumn{2}{c}{ Total } \\
Kecemasan & \multicolumn{2}{c}{ 6-8 tahun } & \multicolumn{2}{c}{$\mathbf{9 - 1 2}$ tahun } & & \\
& $\mathrm{n}$ & $\%$ & $\mathrm{n}$ & $\%$ & $\mathrm{n}$ & $\%$ \\
\hline Rendah & 6 & 13,62 & 21 & 47,74 & 27 & 61,36 \\
Tinggi & 9 & 20,48 & 8 & 18,16 & 17 & 38,64 \\
Total & 15 & 34,1 & 29 & 65,9 & 44 & 100 \\
\hline
\end{tabular}

Tabel 2. Distribusi tingkat kecemasan berdasarkan jenis kelamin

\begin{tabular}{ccccccc}
\hline Tingkat kecemasan & \multicolumn{2}{c}{ Laki-laki } & \multicolumn{2}{c}{ Perempuan } & \multicolumn{2}{c}{ Total } \\
& $\mathrm{n}$ & $\%$ & $\mathrm{n}$ & $\%$ & $\mathrm{n}$ & $\%$ \\
\hline Rendah & 11 & 25 & 16 & 36,36 & 27 & 61,36 \\
Tinggi & 7 & 15,91 & 10 & 22,73 & 17 & 38,64 \\
Total & 18 & 40,91 & 26 & 59,09 & 44 & 100 \\
\hline
\end{tabular}

Tabel 3. Distribusi tingkat kecemasan

\begin{tabular}{ccc}
\hline Tingkat kecemasan & $\mathbf{n}$ & $\mathbf{\%}$ \\
\hline Rendah & 27 & 61,36 \\
Tinggi & 17 & 38,64 \\
Total & 44 & 100 \\
\hline
\end{tabular}

Tabel 4. Distribusi kecemasan anak terhadap perawatan dental

\begin{tabular}{ccc}
\hline Kecemasan terhadap perawatan dental & n & \% \\
\hline Pada dokter gigi? & 81 & 5,14 \\
Pada dokter? & 70 & 4,47 \\
Disuntik? & 143 & 9,08 \\
Bila seseorang memeriksa mulut mu? & 81 & 5,14 \\
Bila diminta membuka mulut? & 71 & 4,51 \\
Bila ada orang yang tidak dikenal menyentuhmu? & 138 & 8,76 \\
Bila diperhatikan orang lain? & 102 & 6,48 \\
Bila gigi mu di-bor oleh dokter gigi? & 122 & 7,75 \\
Bila melihat alat bor dokter gigi? & 122 & 7,75 \\
Pada suara bor dokter gigi? & 111 & 7,05 \\
Bila seseorang memasukkan alat dokter gigi ke dalam mulut mu? & 126 & 8,00 \\
Bila tersedak saat mendapatkan perawatan dental? & 138 & 8,76 \\
Bila harus pergi ke rumah sakit? & 106 & 6,76 \\
Pada orang berpakaian putih? & 78 & 4,95 \\
Total & 85 & 5,40 \\
Bila dokter gigi membersihkan gigi dan mulut mu? & 1574 & 100 \\
\hline
\end{tabular}

\section{BAHASAN}

Kecemasan terhadap perawatan gigi sangat memengaruhi kesehatan gigi dan mulut pada masyarakat. Hal ini menjadi hambatan bagi dokter gigi dalam melaku- kan perawatan. Walaupun telah banyak dilakukan penelitian mengenai kecemasan terhadap perawatan gigi, belum didapatkan solusi yang ampuh untuk menekan kecemasan dental, terutama pada anak. 
Penelitian ini diukur menggunakan kuesioner Children Fear Survey ScheduleDental Subscale (CFSS-DS) yang merupakan suatu alat ukur untuk kecemasan dental pada anak yang terdiri dari 15 pertanyaan,. Dari 15 pertanyaan, terdapat delapan pertanyaan yang menunjukkan situasi dental dan tujuh pertanyaan diluar situasi dental yang mengukur aspek perkembangan kognitif, fisiologis, perilaku, dan emosional pada anak. ${ }^{12}$ Kuesioner ini telah diuji validitas dan reliabilitasnya dan layak digunakan pada penelitian ini.

Hasil penelitian ini menunjukkan bahwa responden dengan tingkat kecemasan rendah paling banyak didapatkan pada rentang usia 9-12 tahun, sedangkan responden dengan tingkat kecemasan tinggi paling banyak didapatkan pada rentang usia 6-8 tahun. Prevalensi tertinggi dari kecemasan ditemukan pada anak usia 6-8 tahun. Hasil ini menunjukkan penurunan tingkat kecemasan pada usia yang lebih tua. Hal ini mungkin disebabkan ketika usia anak meningkat, terjadi perubahan kognitif, karakteristik sosio-emosional, tanggung jawab, penerimaan hal realistis, dan juga pengendalian diri. ${ }^{13}$

Periode usia 6-8 tahun merupakan masa anak sering berhubungan dengan perawatan dental karena pada rentang usia ini banyak terjadi erupsi gigi permanen mulai dari molar pertama, sehingga besar kemungkinan anak akan dihadapkan dengan pengalaman pertamanya mengunjungi dokter gigi dan menimbulkan kecemasan yang berlebihan. ${ }^{14}$ Kecemasan akan perawatan gigi dimulai selama usia awal sekolah dan kemudian menunjukkan penurunan yang sedang seiring bertambahnya usia. ${ }^{15}$

Hasil penelitian ini sejalan dengan penelitian Cuthbert dan Melamed ${ }^{16}$ yang mengungkapkan bahwa usia 6-8 tahun merupakan periode ditemukan kecemasan dental tertinggi dan paling tidak kooperatif selama perawatan gigi. Penelitian yang dilakukan di Indonesia oleh Christian ${ }^{17}$ mengenai perbedaan tingkat kecemasan dental berdasarkan usia dan jenis kelamin terhadap lingkungan perawatan dental pada anak usia 8 dan 11 tahun dengan pengisian kuesioner CFSS-DS. Dari 100 sampel tingkat kecemasan tinggi, terdapat pada anak usia 8 tahun sebesar $27 \%$ dan berdasarkan uji chi-square terlihat perbedaan tingkat kecemasan dental yang bermakna $(\mathrm{p}<0,05)$ antara usia 8 dan 11 tahun. Usia secara bermakna berpengaruh terhadap derajat perilaku kooperatif anak. Hal ini sejalan dengan penelitian yang dilakukan oleh Suprabha ${ }^{18}$ pada anak usia 7-14 tahun yang melaporkan bahwa kemampuan menyesuaikan diri dengan perawatan gigi meningkat seiring dengan bertambahnya usia.

Pada penelitian ini responden dengan tingkat kecemasan rendah meupun tinggi lebih banyak didapatkan pada responden perempuan dibandingkan responden lakilaki. Hal ini mungkin dikarenakan responden yang pernah mendapatkan perawatan gigi lebih banyak ditemukan pada responden perempuan dibandingkan lakilaki.

Penelitian yang dilakukan di Lithuania pada tahun 2006 yang melibatkan responden anak laki-laki dan perempuan di usia sekolah menunjukkan bahwa anak yang pernah mengunjungi dokter gigi sebelumnya memiliki tingkat kecemasan lebih rendah dibandingkan anak yang tidak mengunjungi dokter gigi pada tahun sebelumnya. Penelitian inin dilakukan terhadap responden yang lebih sering mengunjungi dokter gigi pada tahun sebelumnya antara anak laki-laki dan perempuan. Hasilnya lebih banyak anak perempuan yang mengunjungi dokter gigi untuk melakukan perawatan pada tahun sebelumnya $(65,5 \%)$ dibanding anak lakilaki yang hanya $(56,3 \%){ }^{19}$

Jika dibandingkan dengan penelitian yang dilakukan oleh $\operatorname{Rafdi}^{10}$ mengenai gambaran kecemasan anak usia 7-14 tahun di SD Inpres Tamalanrea 2 Makasar didapatkan kecemasan tinggi pada laki-laki sebesar $48,7 \%$ dan pada perempuan sebesar 51,3\%. ${ }^{9}$ Penelitian oleh Man Al-far ${ }^{20}$ di Inggris untuk mengetahui hubungan kecemasan antara perawatan gigi dengan pengalaman anak yang sudah pernah ke 
dokter gigi pada usia 11-14 tahun menunjukkan bahwa secara umum anak perempuan memiliki tingkat kecemasan lebih tinggi dibandingkan dengan anak laki-laki. Berdasarkan bahasan di atas, terlihat secara umum perempuan memiliki tingkat kecemasan yang lebih tinggi dibandingkan laki-laki. Adanya perbedaan ini mungkin disebabkan karena perilaku mengekspresikan nyeri lebih intens pada anak perempuan. Perempuan lebih sering mencari dukungan emosional sebagai strategi bertahan dibanding laki-laki. Hal ini juga bisa menunjukkan bahwa perempuan tahu benar kalau mereka memiliki tingkat ketahanan lebih rendah untuk rasa sakit. $^{21}$

Gambaran kecemasan anak usia 6-12 tahun terhadap perawatan gigi di SD Kristen Eben Haezar 2 Manado dari 44 responden menunjukkan tingkat kecemasan rendah didapatkan pada 27 responden, dan tingkat kecemasan tinggi didapatkan pada 17 responden. Penelitian serupa yang dilakukan oleh Amrullah $^{22}$ mengenai tingkat kecemasan anak sekolah dasar terhadap perawatan gigi di SD Tamalanrea Makasar dengan menggunakan pengisian kuesioner CFSS-DS pada 319 anak mendapatkan sebesar $11,6 \%$ anak mengalami kecemasan tinggi dan $88,4 \%$ anak mengalami kecemasan rendah.

Hal yang paling ditakutkan terhadap perawatan dental berdasarkan kuesioner CFSS-DS pada penelitian ini yaitu penyuntikan. Hal ini mungkin disebabkan karena pada saat peyuntikan menimbulkan rasa nyeri. Hasil penelitian ini sejalan dengan penelitian yang dilakukan oleh Turner et al. ${ }^{23}$ yang menyatakan bahwa anastesi lokal (penyuntikan untuk dilakukan ekstraksi) merupakan tindakan yang paling dicemaskan oleh responden.

\section{SIMPULAN}

Dari hasil penelitian dapat disimpulkan bahwa responden dengan tingkat kecemasan rendah lebih banyak didapatkan pada rentang usia 9-12 tahun sedangkan responden dengan tingkat kecemasan tinggi lebih banyak didapatkan pada rentang usia
6-8 tahun. Baik tingkat kecemasan rendah maupun tinggi lebih banyak ditemukan pada responden berjenis kelamin perempuan.

\section{SARAN}

Disarankan agar seorang dokter gigi lebih memperhatikan faktor-faktor yang memengaruhi tingkat kecemasan pasien terhadap kunjungan ke dokter gigi agar supaya didapatkan kesehatan gigi yang optimal terutama bagi pasien yang mengalami kecemasan dental. Dokter gigi perlu mengetahui dan mengenal tingkat kecemasan pada anak usia sekolah dasar sehingga mampu melakukan penanganan atau perawatan dental yang efektif.

\section{DAFTAR PUSTAKA}

1. Laporan Riset Kesehatan Dasar Nasional 2001. Jakarta: Badan Penelitian dan Pengembangan Kesehatan Kementerian Kesehatan RI (serial online). 2013. p. 135-40. [cited 2016 Mar]. Available from: www. litbang.depkes.go.id.

2. Yustinus S. Teori Kepribadian dan Terapi Psikoanalitik Freud. Yogyakarta: Kanisius, 2006; p. 44-5.

3. Ediasri TA. Perkembangan Anak. Suatu Tinjauan dari Sudut Psikologi Perkembangan. In: Gunarsa SD, Gunarsa YSD Jakarta: BPK Gunung Mulia, 2008.

4. McDonald RE, Avery DR, Dean JA, editors. Dentistry for Child and Adolescence (8th ed). USA: Mosby, 2005; p. 205-6.

5. Nicolas E, Bessadet M, Collado V, Carrasco P, Roger L. Factors affecting dental fear in French children aged 5-12 years. Int J Paeditr Dent. 2010;20;366-73.

6. Alaki S, Alotaibi A, Almabadi E, Alanquri E. Dental anxiety in middle school children and their caregivers: prevalences and severity. J Dent Oral Hyg. 2012;4(1):6-11.

7. Hertanto M. Perbedaan tingkat kecemasan dental berdasarkan usia dan jenis kelamin terhadap lingkungan perawatan dental pada anak usia 6 dan 9 tahun. 2008. [cited 2016 May 19]. Available from: http://www. lontar.ui.ac.id/opac/themes/libri2/detail. jsp?id=125717\&lokasi=lokal

8. Soesilo S. Distraksi sebagai salah satu 
pendekatan yang dilakukan dalam pencapaian perawatan gigi anak. Dentika. 2010;15(1):91-5.

9. Goran K, Poulsen S. Pediatric Dentistry a Clinical Approach (2nd ed). Oxford: Wiley-Blackwell, 2009; p. 35.

10. Rafdi A. Gambaran kecemasan anak usia 714 tahun terhadap perawatan gigi di SD Inpres Tamalanrea Makassar dan SDN 6 Mentirotiku Toraja Utara [Skripsi]. Makassar: Fakultas Kedokteran Gigi Univeristas Hasanuddin; 2014.

11. Lickona T. Mendidik untuk Membentuk Karakter. Jakarta: PT Bumi Aksara, 2012; p. 17-20.

12. Boman UW, Lundgren J, Elfstrom ML, Berggren U. Common use a fear survey schedule for assessment of dental fear among children and adults. Int J Paediatr Dent. 2008;18:70-6.

13. Pinkham JR. Dynamic of changes. In: Pinkham JR, Cassa Massimo PS, editors. Pediatric Dentistry-Infancy through Adolescence (4th ed). Philadelphia: Elsevier Saunders, 2005; p. 469-71.

14. Mohammad RB, Lalithamma T, Varma DM, Sudhakar KNV, Srinivas B, Krishnamraju PV, et al. Prevalence of dental anxiety and its relation to age and gender in coastal Andhra (Visakhaptanam) population, India. J Nat Sci Biol Med. 2014:5(2):409-14.

15. Trismiati. Perbedaan tingkat kecemasan antara pria dan wanita akseptor kontrasepsi mantap di RSUP Dr. Sardjito Yogyakarta. Psyche. 2004; 1(1):103-5.

16. Cuthbert MI, Melamed BG. A screening device: children at risk for dental fears and management problems. ASDC J Dent Child. 1982;49(6):432-6.
17. Christian H. Perbedaan tingkat kecemasan dental berdasarkan usia dan jenis kelamin terhadap lingkungan perawatan dental pada anak usia 8 dan 11 tahun. 2012. Available from: http://lib.ui.ac.id/opac/ui/detail.jsp?id=1 24935\&lokasi=lokal.

18. Suprabha BS, Rao A, Choudhary S, Shenoy R. Child dental fear and behavior: The role of environmental factors in a hospital cohort. Journal of Indian Soc Pedod Prev Dent. 2011;29(2):95-101.

19. Brukiene V. Is dental treatment experience related to dental anxiety? Stomatologija. 2006;8(4):108-15.

20. Al-Far M, Habahbeh N, Al-Saddi R, Rassas E. The relationship between dental anxiety and reported dental treatment experience in children aged 11 to 14 years. JRMS. 2010;19 (2):449.

21. Asokan A, Rao AP, Mohan G, Reddy NV, Kumar K.. A pain perception comparison of intraoral dental anesthesia with 26 and 30 gauge needles in 6-12-year-old children. Journal of Pediatric Dentistry. 2014;2(2):56-60.

22. Amrullah AA. Tingkat kecemasan anak sekolah dasar usia 6,9 , dan 12 tahun terhadap perawatan gigi. Makassar: Fakultas Kedokteran Gigi Universitas Hasanuddin; 2012.

23. Turner S, Chambers SA, Freeman R. Measuring dental anxiety in childrenwith complex and additional support need using Modified Child Dental Anxiety Scale (faces) (MCDASf). Journal of Disability and Oral Health. 2012;13(1):3-10. 